STUDIA PRAWNO-EKONOMICZNE, T. CX, 2019

PL ISSN 0081-6841; e-ISSN 2450-8179 $\quad$ s. 115-130

https://doi.org/10.26485/SPE/2019/110/7

\title{
FINTECH BETWEEN REGULATORY UNCERTAINTY AND MARKET FRAGMENTATION. WHAT ARE THE PROSPECTS FOR THE TECHNOLOGICAL SINGLE MARKET OF FINANCIAL SERVICES?
}

\begin{abstract}
(Summary)
The sector of financial services is in the middle of a unique upheaval, known as FinTech, deriving from the application of emerging technologies to finance. FinTech is a large and heterogeneous ecosystem, variously articulated, that is boosting the digital transformation of the financial sector through a process of change and challenge for all stakeholders. Faced with benefits and risks, different regulatory approaches have been adopted by the Member States so much to affect negatively the main purpose that is the creation of a technological single market of financial services. Different obstacles hinder the achievement of this purpose, among which regulatory gap and legislative uncertainty that fragment the market and encourage regulatory arbitrage. The scheme of the regulatory sandbox could bring down barriers, only if it moves from a national market to a European single one.
\end{abstract}

Keywords: FinTech Ecosystem; national approaches; regulatory barriers; regulatory sandboxes Classification JEL: G28, G29, K39

\section{The FinTech Ecosystem: introductory profiles}

In the era of digital society and economy, the digitalization of the financial sector is playing a growing role by virtue of the application of emerging technologies. New forms of interaction between customers and companies,

* Associate Professor of Financial Markets and Digital Innovation Law at University of Bari - Italy; e-mail: mariateresa.paracampo@uniba.it 
innovative methods of financial supply, reduction of costs and easy access to the same services by an increased number of consumers, financial inclusion and sustainable development, greater competition among companies on the market: these are only some purposes that Fintech is promising for the near future.

Defined by the Financial Stability Board in general terms - not codified - "technology-enabled innovation in financial services that could result in new business models, applications, processes or products with an associated material effect on the provision of financial services" ${ }^{\text {, }}$ FinTech can be considered as a wide and heterogeneous ecosystem that keeps different articulations or structures, more or less diffused on the market, that can be considered "as financial activities which provide an added value by means of digital technologies"2.

Consequently, the minimum criteria to define a FinTech service have been proposed by the European Parliament in the following statements:

- "It is a technology-driven financial service,

- which provides a new solution, a new business model or an alternative to what already exists in the financial sector,

- and offers a significant added value to any of the stakeholders involved in the value chain (mainly the consumer)".

FinTech acquires a double meaning, being defined as a genus or a phenomenon intended in its overall, or as an adjective that defines a company on the basis of the service provided and activated by new technologies (i.e. Big Data Analytics, Artificial Intelligence, Machine Learning, etc.).

The innovative financial solutions, made now possible, derive from the diffusion of online platforms operated by algorithms even more sophisticated.

In fact, the FinTech ecosystem contains comparison (comparison websites), investment (robo advice), funding (equity crowdfunding) or lending (P2P lending), crowdfunding, trading or exchange platforms on one hand, on the other it counts very innovative solutions of the financial sector as blockchain, distributed ledger technology, cryptocurrencies, ICO, etc. FinTech is much more; it succeeds and acquires new forms parallel to the complexity of the applied technology and of the underlying algorithms. Reason for which FinTech gets out of any form of temporal crystallization, being a sort of passe-partout, used to refer to the phenomenon intended as a whole or to a distinctive label regarding all that

1 FSB, Financial Stability Implications from Fintech. Supervisory and Regulatory Issues that Merit Authorities'Attention, 27 June 2017, http://www.fsb.org/wp-content/uploads/R270617.pdf

2 European Parliament, Competition issues in the Area of Financial Technology (FinTech), July 2018, p. 47, http://www.europarl.europa.eu/RegData/etudes/STUD/2018/619027/IPOL STU(2018)619027_EN.pdf 
is innovative from a technological point of view in the performance of financial services or in the production of new products as well as in the implementation of new models of business. At the same time the relative perimeter remains fluid and extends differently to include new solutions or to consider them more evolved than those already existed on the basis of the simultaneous evolution and of the greater complexity of the underlying technologies used.

\section{FinTech and the purpose of a revolutionary phenomenon}

There are numerous benefits for consumers and many opportunities for companies $^{3}$, linked to the diffusion of a phenomenon considered revolutionary ${ }^{4}$ with a strong impact on the financial sector, imposing a severe technological restyling 5 to the traditional operators. The new imperative is "to meet the technological challenge and to compete on the market", where competition is becoming even more intense following the entry of new players (i.e. start ups FinTech or newcomers, GAFA or BigTech), with different regulatory status and not always subject to the same rules applicable to traditional subjects which are gaining market share, disintegrating consolidated structures with the risk of financial disintermediation.

The current modifications have been resumed in a single key-word ${ }^{6}$ : 'change', that assumes a double meaning - premise or consequence-depending on the immediate aim recognized to FinTech, respectively that of digital transformation or, on the contrary, that of digital disruption of the financial sector.

3 The positive aspects of FinTech are fully explained by the European Parliament in its first significant examination of the ecosystem together with the individualization of critical profiles to be monitored [Resolution of 17 May 2017 on FinTech: the influence of technology on the future of the financial sector (2016/2243(INI), http://www.europarl.europa.eu/sides/getDoc. do?pubRef=-//EP//TEXT+TA+P8-TA-2017-0211+0+DOC+XML+V0//EN].

4 The same revolutionary process is developing in the insurance field, better known as InsurTech.

5 This also emerges from the last two reports published by EBA on 3 July 2018: the first one (Report on the impact of FinTech on incumbent credit institutions' business models) expands on the analysis concerning the benefits and risks of some specific technologies (i.e. biometric, robo advice, artificial intelligence, cloud, etc.) that incumbents should take into consideration in the near future; with the second one (Report on the prudential risks and opportunities arising for institutions from FinTech) the Authority indicates the path of some actions that the incumbents are adopting or can adopt in order to compete on the market with the new players.

6 European Parliament, Competition issues in the Area of Financial Technology (FinTech), p. 103. 
In short, it is characterized by a severe influence exercised by new technologies on the service provided, on the typology of players that can compete on the market, on the mode which the FinTech services can be rendered with.

'Change' should be combined with another word that resumes further purposes surrounding FinTech: 'challenge', where on one hand the change constitutes a real challenge for all stakeholders involved, on the other hand, the challenge becomes reason and driving force for a change in the financial sector and system intended as a whole.

Indeed, the challenge is also the word preceding the change, the result of a precise choice in dealing with the necessary digital transformation in order to compete on the market or to regulate and to supervise the market - to protect consumers and financial stability - with regard to the use of new technologies in the performance of financial services.

In fact, each innovation on the market - be technological, be financial - means inevitably a challenge for regulators and supervisors enough to draw increasing attention on FinTech or on the single articulations of the large ecosystem, making them rise to real "supervised special awaiting regulatory judgement"

\section{FinTech and the goal of the technological single market of financial services}

The final objective of the ongoing process is to create a single technological market of financial service as a European pole for FinTech that can compete at global level with the mature ones as Asian and America ones as well as affirm its European leadership ${ }^{8}$ in specific contexts linked to the technological innovation (i.e. blockchain) ${ }^{9}$.

M.-T. Paracampo, Robo-Advisor, consulenza e profili regolamentari: quale soluzione per un fenomeno in fieri?, Rivista Trimestrale di Diritto dell'Economia 2016/4, supplemento, p. 256.

8 European Commission, A renewed European Agenda for Research and Innovation - Europe's chance to shape its future, $\operatorname{COM(2018)} 306$ final, 15 May 2018, https://ec.europa.eu/info/ sites/info/files/com-2018-306-a-renewed-european-agenda-_for_research-and-innovation may_2018_en_0.pdf

9 A such invitation has been recently proposed to the European Commission by the Parliament with the resolution of 3 October 2018 on distributed ledger technologies and blockchains: building trust with disintermediation (2017/2772(RSP)), http://www.europarl.europa.eu/ sides/getDoc.do?pubRef=-//EP//NONSGML+TA+P8-TA-2018-0373+0+DOC+PDF+V0//IT, that is within the initiatives proposed by the European Commission to explore the Distributed 
An ambitious purpose that is set in a European framework much more articulated, considering that FinTech becomes the connecting point of different working tables open almost simultaneously by the European Commission: expression on the financial side of the digital single market ${ }^{10}$ that meets the needs expressed by the Financial Services Action Plan and gives an acceleration in the realization of the Capital Markets Union of which it is an important part. This is what emerges from the converging deadline for the realization set for 2019.

It is a large and complex project, whose ranks are held by the European Commission which has to coordinate the work, taking into consideration other two contributing factors: first of all, the process of financial convergence of the European supervisory practice on financial matters ${ }^{11}$, that could change the guidelines aimed at the supervisory practices and the skills of the European Authorities; on the other hand, Brexit that can affect significantly the competitive side, having gained some experience in the field FinTech and regulatory sandbox, followed and reproduced successfully also by Asian Authorities (i.e. Hong Kong and Singapore).

These are the main coordinates of a constantly evolving scenario that, according to the European Commission, should provide the innovation imprinting to the services already provided, to the products already distributed, to the business models adopted, to the technologies applied to financial services.

\section{FinTech, regulatory approaches and emerging issues}

The first phases of FinTech dissemination process on the market have not been linear, failing unanimous consensus. The disruptive implication of FinTech is accompanied by often heated debate with different orientations on the phenomenon purposes, potentialities and related benefits, above all on relative risks for consumer protection and financial stability, on regulatory approaches to adopt. FinTech builds consensus in support of digital innovation and new technologies applied to the financial sector, but also meets with the dissent of who puts in evidence its risks for the financial system intended as a whole.

Ledger Technology (DLT), among which "Blockchain4EU: Blockchain for industrial transformations", "EU Observatory and Forum on Blockchain", "Blockchain for the social good" and the "Study on the opportunity and feasibility of a EU blockchain structure".

10 European Commission, Completing a trusted Digital Single Market for all [COM(2018) 320 final, 15 May 2018], https://ec.europa.eu/commission/sites/beta-political/files/commu nication-trusted-digital-single-market-for-all_en.pdf

11 European Commission, Reinforcing integrated supervision to strengthen Capital Markets Union and financial integration in a changing environment [COM(2017) 542 final del 20 settembre 2017], https://eur-lex.europa.eu/legal-content/IT/TXT/PDF/?uri=CELEX:52017DC0542\&from=en 
This dichotomy is a characterizing and distinctive element of the first introductory approach to the phenomenon ${ }^{12}$ based on a bifocal vision that takes into account benefits and risks both for consumers and companies.

The different perspectives in the debate and the lack of unanimity of views and interpretation of a phenomenon constantly evolving have characterized two different moments of the in-depth analysis of the theme which is still ongoing.

If in the first phase, following the financial crisis, the increased needs for innovation and the simultaneous offer of financial solutions, alternative to the traditional ones, have risen growing interest among National and European Authorities, European Institutions and International Bodies, while in a second phase this interest, with the need of a better understanding and deepening of the dynamic technologies underlying the different articulations of the heterogeneous FinTech ecosystem, have found their expression in a huge number of documents, sometimes redundant both in the quite standardized setting of published documents and in their contents. A script that, proposed in the same terms at national, European and international level, has overlapped some of the contributions often compartmentalized and dealt with the same relevant areas. Certainly, this has not contributed to a better understanding of the phenomenon, but it has risen a problem of coordination of the sources with the risk of a further fragmentation of the framework applied to the single and concrete case.

At the same time, in different cases and in many jurisdictions, FinTech, considered as a genus, has moved at different speeds, including more or less evolved cases. The greater or lower pressure is significantly determined in each case by the existence or not of a regulatory framework or gap.

In most cases FinTech has been considered already at an initial phase of development and diversely configured in its different articulations enough to justify a prudence-oriented-approach by European Authorities which have considered premature to intervene with specific measures in certain areas.

It is well known the case of the automated financial advice taken into consideration by the ESAs that, after having considered sufficient the consumer protection offered by the sectorial legislation, have assured an ongoing monitoring on the sector development ${ }^{13}$. After two years the response has not

12 For a better reconstruction of the different interventions on the ecosystem FinTech, see M.-T. Paracampo (edited by), FinTech e il mercato unico tecnologico dei servizi finanziari, in: FINTECH. Introduzione ai profili giuridici di un mercato unico tecnologico dei servizi finanziari, Giappichelli 2017, p. 1.

13 ESAs, Report on automation in financial advice, December 2016, https://esas-joint-committee. europa.eu/Publications/Reports/EBA\%20BS\%202016\%20422\%20(JC\%20SC\%20CPFI\%20 
changed, the Authorities have stated to continue in the exercise of the market monitoring due to a slow increase of the phenomenon.

At the same time, an identical orientation (i.e. a tentative approach characterizes exclusively by a continuous monitoring) has been adopted also with reference to Big Data used by financial institutions, although in this case the failure to adopt any regulatory measure or any other kind of it has been accompanied by some good practices suggested by companies which already use Big Data ${ }^{14}$. At present, the scenario is still confused. In particular, it is evident a particular confusion in almost all published documents in this matter concerning what has to be regulated and what kind of regulatory instrument has to be adopted or not, concerning hard or soft law.

Moreover the solutions offered are influenced by the sources of origin and by the kind of mandate that each authority, institution or body has to accomplish on national, European and international level as well as by the concrete case, object of the regulatory response, and by the existence or non-existence of a regulatory framework, by the potential imputability of an innovative case to the existing legislation and by the possible legal qualification offered in different jurisdiction with regard to the theme on which the specific interest is focused (i.e. cryptocurrencies, Initial Coin Offering, etc. $)^{15}$.

Final\%20Report\%20on\%20automated\%20advice\%20tools).pdf

The response by ESAs is in line with that already expressed by IOSCO, Update to the Report on the IOSCO Automated Advice Tools Survey. Final Report, FR15/2016, December 2016, http://www.iosco.org/library/pubdocs/pdf/IOSCOPD552.pdf

14 ESAs, Joint Committee Final Report on Big Data, JC/2018/04 - 15 March 2018, https://www. esma.europa.eu/sites/default/files/library/jc-2018-04_joint_committee_final_report_on_big_ data.pdf

15 The approaches proposed at international level are numerous and different in contents. It should be noted, inter alia: Ch. Lagarde, A Regulatory Approach to Fintech, in: Finance \& Development, Finance \& Development, March 2018/55/2, https://www.imf.org/external/ pubs/ft/fandd/2018/06/how-policymakers-should-regulate-cryptoassets-and-fintech/straight. pdf; B. Coeuré, Financial regulation and innovation: a two-way street, Berlin 14 March 2018, https:/www.ecb.europa.eu/press/key/date/2018/html/ecb.sp180314.en.html; M. Kadievska-Vojnovik, FinTech and digital transformation: "Regulating an anonymous world", Belgrade 22-23 May 2018, https://www.bis.org/review/r180611e.htm; F. Groepe, The FinTech phenomenon: five emerging habits that may influence effective fintech regulation, Pretoria 19 April 2018, https://www.bis.org/review/r180426e.htm

At European level it is important to mention: A. Enria, Designing a Regulatory and Supervisory Roadmap for FinTech, Speech, Copenhagen Business School, 9 March 2018, https:/www.eba.europa.eu/documents/10180/2151635/Andrea+Enria\%27s+speech+on+FinTech+at+Copenhagen+Business+School+090318.pdf; Steven Maijoor, Keynote Address: A Misured Approach to FinTech, ESMA71-319-70/27 February 2018, https://www.esma. 


\section{Lack of harmonized law, regulatory uncertainty and market fragmentation}

In order to promote the process of digital transformation and to sustain innovation, the key-purposes of the work carried out by institutions and, at the same time, the driving forces for the growth and the development of the European market, the national authorities have adopted different approaches concerning FinTech or only a single articulation.

The options preferred by some Member States have been translated in different explorative analysis of the theme, initiatives regarding the access to the market by FinTech start ups, support measures and testing of innovative financial solutions.

First of all, FinTech, or better the current configured scenario with its many aspects, suffers from a certain "overcrowding" due to the attention received by different subjects (i.e. regulators, supervisors, national and European institutions, international bodies) whose skills, diffused at different latitudes, often overlap due to an intense difficult in the process of understanding and regulation of an innovative phenomenon and above all of new technologies. Hesitation that has determined a regulatory patchwork at a European level (even more pronounced in the international regulatory gap), characterized by legislative gap and different approaches by the Member States and by the competent authorities in a cross border contest. And this not only with reference to FinTech intended as a genus, but also in relation to the single articulations.

The difficult is also amplified, as already pointed out, by different level of intervention (at national, European and international level) and by a plurality of European institutions and international authorities and bodies as well as by the problems relative to the lack of coordination by the same and by the overlapping of skills for certain areas needed to be monitored with the risk of obtaining contrasting and/or contradictory answers.

The regulatory environment that characterizes FinTech is also the result of a combination of vertical interventions in this sector that involve - by virtue of the principle of technological neutrality - the application of sectorial discipline in financial matters (i.e. MiFID 2, IDD, MCD), with others of horizontal type (i.e. GDPR, NIS, AML). The branched system is interested by other interventions with a transversal connotation focused on the use of emerging technologies (i.e. Big Data,

europa.eu/sites/default/files/library/esma71-319-70_second_annual_fintech_and_digital_innovation_conference stanhope_hotel_brussels.pdf 
artificial intelligence, machine learning, cloud computing, etc.) in different sectors of financial market and, above all, in the performance of different financial services.

In view of the description, the definition of a technological single market of financial services - behind the initial proclamation - has proved to be challenging, showing different elements of weakness that interfere with the achievement of the main purpose.

Many legislative and operative barriers risk to produce the fragmentation of the market that reflects on the stability and efficiency of the financial system, being, at the same time, cause and effect of diffused forms of regulatory arbitrage ${ }^{16}$, together with anti-competitive pressure.

At the origin of these barriers to market access and to the cross border operativity, there are, first of all, the regulatory gap on different cases included in FinTech ecosystem; the lack of an harmonized discipline in the different Member States; evident signs of disharmony and legislative uncertainties concerning the qualification of FinTech services really provided as well as on the applicable rules; legal uncertainty on the regulatory status to recognize to the players involved.

If the regulatory barriers such as the complexity of existing applicable regulation, such as MiFID 2/MiFIR, IDD, GDPR, PRIIPs (especially for smaller firms), are becoming an established reason of the slowdown in the growth of certain phenomena on the market ${ }^{17}$, the absence of a complete harmonization of the sectorial regulation in financial matters breaches the exercise of discretion of the Member States in the introduction of additional requirements compared to those pursuant to European law ${ }^{18}$.

The co-existence in the European framework of many regulatory regimes creates not only a patchwork of different rules, but it can be at the origin of both forms of regulatory arbitrage by operators, encouraged to provide services in countries characterized by less rigorous discipline and of possible discriminatory treatment of consumers situated in countries characterized by more rigorous regimes.

16 D. Ahern, Regulatory Arbitrage in a FinTech World: Devising an Optimal EU Regulatory Response to Crowdlending, European Banking Institute Working Paper Series, 2018 - no. 24, 18 April 2018, https://papers.ssrn.com/sol3/papers.cfm?abstract_id=3163728

17 This is the case of automation in financial advice as reported recently by ESAs in Joint Committee Report on the results of the monitoring exercise on 'automation in financial advice' (JC 201829, 5 September 2018), https://esas-joint-committee.europa.eu/Publications/Reports/JC\%20 2018\%2029\%20-\%20JC\%20Report\%20on\%20automation\%20in\%20financial\%20advice.pdf

18 An example is the Directive (EU) 2016/97- Insurance Distribution Directive (IDD) that is based on the principle of minimum harmonization. 
The regulatory fragmentation among different Member States is not only cause of a reduced competition among national legislations, but it also discourages the cross-border operation that can render more cohesive and functioning the single market.

\section{Towards an European Strategy on FinTech}

Against a fragmented regulatory scenario and a market consultation, the European Commission has published the FinTech Action Plan, in which it defines the most critical areas that require an immediate action for the period 2018/2019. Areas confirmed in the Roadmap for FinTech drawn up by EBA, to which the European Commission gives a series of examination and exploratory mandates that serve the introduction of best practices, guidelines or other instruments of soft law.

Both documents are to be intended parallel, because they integrate the European Strategy for the creation of a technological single market of financial services.

Among the programmed interventions, there is one characterized by high priority and concerns the access to the market by FinTech's subjects and, in particular, the regulatory authorization intended as a preliminary and functional moment included within the supervision by authorities and concurrent subjection to a complex and almost "ungovernable" set of rules.

It is a sensitive issue that requires careful consideration, particularly when two complementary aspects arise and, together, risk causing a devastating outcome in relation to the desired drive for innovation: on one hand, the regulatory uncertainty concerning the applied regime in some cases and, on the other hand, the lack of clarity in relation to the regulatory status of some companies.

The theme of the authorization is one of the most controversial on the working table on FinTech, involving on one hand the compliance with the principle of level playing field, on the other, the promotion of a healthy and fair competition, together with the support of the innovation principle that, already in the objectives set by the European Parliament in the Resolution of 17 May 2017, represented one of the most important factors of the policy to adopt with regard to FinTech.

The European license will permit to the FinTech start ups to carry out and to provide innovative services at cross-border level, breaking down the 
administrative barriers and obstacles that prevent the cross border activity and fragment the domestic market further on.

The license or European passport issued for FinTech companies meets the need of creating the support for a harmonized regulatory framework on this issue and, at the same time, creating the conditions for a regulatory environment that encourages digital innovation.

Of the same opinion is the regulatory proposal made by European Commission on service providers of investment based and lending based crowdfunding, area characterized by severe regulatory gaps in the Member States.

The introduction of a special licence in this case also represents a sort of experiment, considering that the Commission has not excluded the extension of it to other sectors included in the ecosystem FinTech.

Nevertheless the direction undertaken by the Commission aims to identify, through EBA, the authorization requirements that are divergent and affect the companies FinTech, getting on with the work in order to:

- "clarify the EU legislative framework applied to services;

- evaluate the necessity of an EU framework for new models of innovative business;

- provide guidelines to National Supervisory Authorities in order to guarantee a better convergence among national regulatory regimes".

\section{National regulatory sandbox vs. European regulatory sandbox vs. global network: what kind of solution for the technological single market of financial services? Some final considerations}

In the confused framework that still characterizes FinTech and its articulations new solutions arise with the aim of bringing down regulatory barriers and legislative uncertainty that facilitate the fragmentation of the market. Options that materialize in little elementary discipline planned by the European Commission to bridge the gap (i.e. proposal of regulation on crowdfunding service providers), making use of soft law instruments (i.e. guidelines, recommendations, opinions, etc.) in order to harmonize action good practices for companies on one hand and supervisors' intervention by the other hand, and that find their expression in spaces of controlled experimentation.

They are "protected spaces" whose introduction has been recommended to the national authorities by European Parliament with the aim of testing 
new technological proposals and, at the same time, supporting innovation, exonerating - on the basis of an evaluation carried out by chance - from the application of a complete regulatory set or of a supervision through a comparison among companies, regulators and supervisors.

The schemes of concretization are different and move from regulatory sandboxes through innovation hubs to incubators.

Although the model of regulatory sandbox is the most appreciated at European and Extra-european level following the example of that created by the British FCA, it is also true that the characteristics of the sandboxes vary in the different Member States which have implemented them, for example with reference to the category of subjects admitted, if extended also to the new players or only to the incumbents, for the purposes of financial services and limitations on the regulatory obligations applied and on the license. All the profiles have determined a further hypothesis of fragmentation both in regulatory approaches to the theme in general and in the solutions selected on different sides involved and experimented on a case-by-case basis, with an inevitable and undesired effects.

The approach of each sandbox, limited to the national domain, excludes in consequence - in a cross border dimension - the accession the market of all new incoming and outgoing players, for reasons of different indications, sometimes contrasting, about the status recognized to the innovative companies and the application of a regulatory set, becoming a further operative 'burden', in order to stimulate other forms of arbitrage - besides those already described - to the detriment of the cross-border performance.

In an attempt to standardize these features and in line with FinTech Action Plan, EBA $^{19}$ is carrying out a mapping of the different regimes of sandbox that are widely diffused in order to identify the best practices to implement by those already operative and those that will implement in the future. This solution should offer a balanced approach between the support to the innovation and the digital transformation in order to guarantee compliance with the principle of level playing field. It should be recalled that $\mathrm{EIOPA}^{20}$ is carrying out a similar

19 EBA Industry Roundtable: Regulatory Sandboxes and Innovation Hubs, EBA's premises, London, 3 September 2018, https:/www.eba.europa.eu/documents/10180/2270871/Presenta tion + for + industry + roundtable $+\% 28$ sandboxes + and + IHs $\% 29 \% 20$ September $+2018+-$ + for+publication.pdf; CEPS-ECRI, The Future of Retail Financial Services. What policy mix for a balanced digital transformation?, Report of a CEPS-ECRI Task Force, February 2017, https://www.ceps.eu/system/files/TFRFutureFinancialServices.pdf

20 EIOPA's InsurTech Insight Survey, July 2018, https://eiopa.europa.eu/Pages/Surveys/EIOPAsInsurTech-Insight-Survey.aspx 
action in the insurance field as that activated by EBA, measure that could determine a fragmentation not only of the market, but also sectorial.

Considering the common interests, it would also be desirable a uniform and joined up approach carried out by the Joint Committee of ESAs to avoid cross border and cross sector fragmentations that would negatively affect the technological single market of financial services. The second option is something different and it is well supported, because it is in favor of the creation of a European regulatory sandbox ${ }^{21}$, in which debate and solutions to adopt are focused in order to share in all Member States those ones reached at European level.

This hypothesis could contribute to the process for the creation of a European competitive process for FinTech, being a multidisciplinary environment, also open to the research of new technologies with all skills necessary for a better evaluation.

We should not forget the competitive factor in view of the Brexit with all considerable experience matured in the field FinTech.

In fact the regulatory sandbox, created by FCA, in addition to being a precursor of those implemented thereafter, has finalized different cooperation agreements to share information and experiences, among the others, with Hong Kong and Singapore Authorities, strengthening its competitive position on the market so much to have launched a consultation to explore the opportunities of an approach at international level, whose aim is to create the Global Financial Innovation Network ${ }^{22}$.

In a forward-looking perspective, if this solution takes root because of its appropriateness at international level, the European regulatory sandbox will be entitled to adhere and, at the same time, to compete, taking care of its ongoing technological leadership to export outside Europe.

21 EBA, REGULATORY SANDBOXES. A proposal to EBA by the Banking Stakeholders Group, 20 July 2017, https://www.eba.europa.eu/documents/10180/807776/BSG+Paper+ on+Regulatory+Sandboxes_20+July+2017.pdf; EBF, Report on Innovate. Collaborate. Deploy. The EBF vision for banking in the Digital Single Market, 14 November 2016, https:// www.ebf.eu/wp-content/uploads/2017/05/EBF-vision-for-banking-in-the-Digital-SingleMarket-October-2016.pdf; W.-G. Ringe, Ch. Ruof, A Regulatory Sandbox for Robo Advice, EBI Working Paper Series, May 2018/26, https://papers.ssrn.com/sol3/papers.cfm?abstract_ id $=3188828$

22 FCA, Global Financial Innovation Network (GFIN).Consultation document, August 2018, www.fca.org.uk 


\section{References}

Ahern Deirdre, Regulatory Arbitrage in a FinTech World: Devising an Optimal EU Regulatory Response to Crowdlending, European Banking Institute Working Paper Series, 2018 - no. 24, 18 April 2018, https://papers.ssrn.com/sol3/papers.cfm?abstract id=3163728

CEPS-ECRI, The Future of Retail Financial Services. What policy mix for a balanced digital transformation?, Report of a CEPS-ECRI Task Force, February 2017, https://www.ceps.eu/ system/files/TFRFutureFinancialServices.pdf

Coeuré Benoit, Financial regulation and innovation: a two-way street, Berlin 14 March 2018, https:/www.ecb.europa.eu/press/key/date/2018/html/ecb.sp180314.en.html

EBA, EBA Industry Roundtable: Regulatory Sandboxes and Innovation Hubs, EBA's premises, London, 3 September 2018, https://www.eba.europa.eu/documents/10180/2270871/Presenta tion+for+industry+roundtable+\%28sandboxes+and+IHs\%29\%20September+2018++ for + publication.pdf

EBA, The EBA's FinTech Roadmap. Conclusions from the consultation on the EBA's approach to Financial Technology (FINTECH), 15 March 2018, https://www.eba.europa.eu/documents/ 10180/1919160/EBA+FinTech+Roadmap.pdf

EBA, REGULATORY SANDBOXES. A proposal to EBA by the Banking Stakeholders Group, 20 July 2017, https:/www.eba.europa.eu/documents/10180/807776/BSG+Paper+on+ Regulatory+Sandboxes_20+July+2017.pdf

EBA, Report on the impact of FinTech on incumbent credit institutions'business models, 3 July 2018, http://www.eba.europa.eu/documents/10180/2270909/Report+on+the+impact +of+ Fintech+on+incumbent + credit + institutions $\% 27 \% 20$ business + models.pdf

EBA, Report on the prudential risks and opportunities arising for institutions from FinTech, 3 July 2018, http://www.eba.europa.eu/documents/10180/2270909/Report+on+prudential+ risks+and+opportunities+arising+for+institutions+from+FinTech.pdf

EBF, Report on Innovate. Collaborate. Deploy. The EBF vision for banking in the Digital Single Market, 14 November 2016, https://www.ebf.eu/wp-content/uploads/2017/05/EBF-visionfor-banking-in-the-Digital-Single-Market-October-2016.pdf

EIOPA, EIOPA's InsurTech Insight Survey, July 2018, https://eiopa.europa.eu/Pages/Surveys/ EIOPAs-InsurTech-Insight-Survey.aspx

EnriaAndrea, Designing a Regulatory and Supervisory RoadmapforFinTech, Speech, Copenhagen Business School, 9 March 2018, https://www.eba.europa.eu/documents/10180/2151635/ Andrea+Enria\%27s + speech+on+FinTech + at + Copenhagen+Business + School+090318.pdf

ESAs, Joint Committee Final Report on Big Data, JC/2018/04 - 15 March 2018, https://www esma.europa.eu/sites/default/files/library/jc-2018-04_joint_committee_final_report_on_ big_data.pdf

ESAs, Joint Committee Report on the results of the monitoring exercise on 'automation in financial advice', JC 2018-29, 5 September 2018, https://esas-joint-committee. europa.eu/Publications/Reports/JC\%202018\%2029\%20-\%20JC\%20Report\%20on\%20 automation\%20in\%20financial\%20advice.pdf

ESAs, Report on automation in financial advice, December 2016, https://esas-joint-committee. europa.eu/Publications/Reports/EBA\%20BS\%202016\%20422\%20(JC\%20SC\%20 CPFI\%20Final\%20Report\%20on\%20automated\%20advice\%20tools).pdf 
European Commission, A renewed European Agenda for Research and Innovation - Europe's chance to shape its future, $\operatorname{COM(2018)} 306$ final, 15 May 2018, https://ec.europa.eu/info/ sites/info/files/com-2018-306-a-renewed-european-agenda- for research-and-innovation may_2018_en_0.pdf

European Commission, Completing a trusted Digital Single Market for all [COM(2018) 320 final, 15 May 2018], https://ec.europa.eu/commission/sites/beta-political/files/communicationtrusted-digital-single-market-for-all_en.pdf

European Commission, FinTech Action plan: For a more competitive and innovative European financial sector, $\operatorname{COM(2018)~} 109$ final, 8 March 2018, https://eur-lex.europa.eu/resource. html?uri=cellar:6793c578-22e6-11e8-ac73-01aa75ed71a1.0017.02/DOC_1\&format=PDF

European Commission, Proposal for a Regulation of the European Parliament and of the Council on European Crowdfunding Service Providers (ECSP) for Business, COM(2018) 113 final, 8 March 2018, https://ec.europa.eu/info/law/better-regulation/initiatives/ares2017-5288649_en

European Commission, Reinforcing integrated supervision to strengthen Capital Markets Union and financial integration in a changing environment [COM(2017) 542 final del 20 settembre 2017], https://eur-lex.europa.eu/legal-content/IT/TXT/PDF/?uri=CELEX:52017DC0542\&from=en

European Parliament, Competition issues in the Area of Financial Technology (FinTech), July 2018, http://www.europarl.europa.eu/RegData/etudes/STUD/2018/619027/IPOL_STU (2018)619027_EN.pdf

European Parliament, Resolution of 17 May 2017 on FinTech: the influence of technology on the future of the financial sector (2016/2243(INI), http://www.europarl.europa.eu/sides/getDoc. do?pubRef=-//EP//TEXT+TA+P8-TA-2017-0211+0+DOC+XML+V0//EN

European Parliament, Resolution of 3 October 2018 on distributed ledger technologies and blockchains: building trust with disintermediation, http://www.europarl.europa.eu/sides/ getDoc.do?pubRef=-//EP//NONSGML+TA+P8-TA-2018-0373+0+DOC+PDF+V0//IT

FCA, Global Financial Innovation Network (GFIN). Consultation document, August 2018, www. fca.org.uk

FSB, Financial Stability Implications from Fintech. Supervisory and Regulatory Issues that Merit Authorities'Attention, 27 giugno 2017, http://www.fsb.org/wp-content/uploads/R270617.pdf

Groepe Francois, The FinTech phenomenon: five emerging habits that may influence effective fintech regulation, Pretoria 19 April 2018, https://www.bis.org/review/r180426e.htm

IOSCO, Update to the Report on the IOSCO Automated Advice Tools Survey. Final Report, FR15/2016, December 2016, http://www.iosco.org/library/pubdocs/pdf/IOSCOPD552.pdf

Kadievska-Vojnovik Maja, FinTech and digital transformation: "Regulating an anonymous world”, Belgrade 22-23 May 2018, https://www.bis.org/review/r180611e.htm

Lagarde Christine, A Regulatory Approach to Fintech, in: Finance \& Development, Finance \& Development, March 2018/55/2, https:/www.imf.org/external/pubs/ft/fandd/2018/06/ how-policymakers-should-regulate-cryptoassets-and-fintech/straight.pdf

Maijoor Steven, Keynote Address: A Misured Approach to FinTech, ESMA71-319-70/27 February 2018, https://www.esma.europa.eu/sites/default/files/library/esma71-319-70_ second_annual_fintech_and_digital_innovation_conference_-_stanhope_hotel_brussels.pdf

Paracampo Maria-Teresa, Robo-Advisor, consulenza e profili regolamentari: quale soluzione per un fenomeno in fieri?, Rivista Trimestrale di Diritto dell'Economia 2016/4, supplemento, p. 256. 
Paracampo Maria-Teresa (ed.), FinTech e il mercato unico tecnologico dei servizi finanziari, in: FINTECH. Introduzione ai profili giuridici di un mercato unico tecnologico dei servizi finanziari, Giappichelli, 2017, p. 1.

Ringe Wolf-George, Ruof Christopher, A Regulatory Sandbox for Robo Advice, EBI Working Paper Series, May 2018/26, https://papers.ssrn.com/sol3/papers.cfm?abstract_id=3188828

\section{Maria-Teresa PARACAMPO}

\section{FINTECH - MIĘDZY NIEPEWNOŚCIĄ REGULACYJNĄ I FRAGMENTACJĄ RYNKOWĄ. JAKIE SA PERSPEKTYWY NA JEDNOLITY RYNEK USŁUG FINANSOWYCH?}

$$
\text { (Streszczenie) }
$$

Sektor usług finansowych obecnie wszedł w erę wyjątkowego zawirowania, określanego mianem Finch. Jego przyczyna wynika z zastosowania nowoczesnych technologii finansowania. FinTech to duży i różnorodny ekosystem, przybierający różne formy. Pobudzają one cyfrową transformację sektora finansowego, co stanowi wyzwanie dla wszystkich uczestniczących w nim podmiotów. Biorąc pod uwagę zarówno korzyści, jak i zagrożenia wynikające ze zmian w sektorze finansowym, państwa członkowskie przyjęły różne mechanizmy prawne wywierające negatywny wpływ na stworzenie jednolitego rynku usług finansowych. Różne przeszkody, w tym luki prawne i niepewność co do prawa, utrudniają realizację tego celu, co z kolei skutkuje rozdrobnieniem rynku i zachęca do arbitrażu regulacyjnego. Schemat piaskownicy regulacyjnej może zmniejszyć bariery tylko wtedy, gdy przeniesie się z rynku krajowego na europejski.

Słowa kluczowe: ekosystem FinTech; podejścia krajowe; bariery regulacyjne; piaskownice regulacyjne 